\title{
Five facets of fulfillment in pediatric radiology
}

\author{
Richard B. Gunderman ${ }^{1}$
}

Received: 27 January 2020 /Revised: 27 January 2020 / Accepted: 11 February 2020 /Published online: 20 February 2020

(C) Springer-Verlag GmbH Germany, part of Springer Nature 2020

It is possible to be a very good pediatric radiologist and still feel empty or even miserable inside. Knowledge, technical skill and experience lie to some extent outside the personality of the practitioner, and those who possess them in greatest abundance are not necessarily the wisest, most compassionate, or happiest members of the field.

To find fulfillment in pediatric radiology, we must look beyond the content of textbooks, lectures and exams to the identity and aspirations of each pediatric radiologist, not only as a professional but also as a human being.

Although rarely discussed in journals, at professional meetings, or in textbooks, there are five facets of fulfillment in pediatric radiology: knowledge, collegiality, courage, gratitude and faithfulness. Each has far less to do with professional credentials or titles than with the moral imagination of every pediatric radiologist.

\section{Knowledge}

To know in the deepest sense means far more than being able to select the correct answer on a multiple-choice exam.

More than being correct, knowing deeply means embodying curiosity, caring about understanding for its own sake, and reveling in discovery. In this context, not knowing should be seen as less an admission of failure than a summons to pursue knowledge.

All knowledge is not created equal. Knowing the email addresses of every pediatric radiologist is of far less moment than knowing how to work up a case, formulate a cogent and useful differential diagnosis, and draw on the expertise of colleagues in assembling a comprehensive picture of what is going on with a patient.

Richard B. Gunderman

rbgunder@iu.edu

1 Department of Radiology, Riley Hospital for Children, Indiana University School of Medicine, 702 North Barnhill Drive, Room 1053, Indianapolis, IN 46202, USA
Medical knowing in its deepest sense aims to make a difference in the lives of human beings, and especially those of the patients for whom we care.

To know what kind of knowledge makes a difference — not just in terms of restoring health but also investing work and life with meaning - is to know something about fulfillment. Knowledge of this sort embodies a commitment to human flourishing, the desire to help others make the most of life.

The goal of flourishing is not to become rich, famous or powerful, nor to enjoy the best of life's creature comforts, but to lead a life of substance that leaves both persons and some small corner of the world enriched.

\section{Collegiality}

This love of knowledge implies a love of collegiality. Collegiality is not about having coworkers who watch our backs, but about colleagues who are co-inquirers, who share a commitment to knowing and being their best as radiologists and human beings.

Such colleagues are not envious or cynical. Instead they embody a genuine concern for one another and the professional community. They delight in one another's flourishing.

We learn the most not from sycophants who applaud our every word but from those who challenge us, push us to question our assumptions, offer evidence that we have not considered, and generally push us to look at matters from new points of view.

Such colleagues contest with one another not to wreak destruction but to join in inquiry, push us to become better than we are, and draw from each of us more than we thought ourselves capable of.

Those who disagree with us are not our inferiors. They too are seekers, operating with an incomplete body of knowledge and experience and, at least at their best, seeking to do what they can to enrich understanding.

From this vantage point, thriving professional communities are not characterized as rooms full of people nodding silently 
in unison, but rooms of colleagues engaged in spirited and sometimes even heated discussion.

\section{Courage}

To acknowledge uncertainty yet press forward in such conversations requires courage. We know more than we can say, and in advocating for the voiceless, seeking to liberate the oppressed, and striving to play our part in healing this broken world, we need the courage of our convictions.

To embody a particular vision of the flourishing health professional is to stake a claim that some things in work and life are more essential than others, and to stick to that vision even under inconvenient circumstances.

Courage means not an unwavering insistence on triumph, but a willingness to suffer for what we believe. To believe, for example, that as pediatric radiologists we are called to enrich the lives of children is to open ourselves up to the possibility of sharing in the suffering of children.

Rather than simply condemning those we deem responsible for abuse or neglect, it means also seeking to understand and redress the economic, social and even spiritual conditions that contribute to it.

Courage means resisting the temptation, when confronted with injustice, cruelty, greed and fear, to simply excuse ourselves from the room by claiming that such matters do not fall within the ambit of our job description.

Courage means answering the call or our human responsibility. No matter what membership cards we may or may not carry in our pocketbooks, we are all moral perceivers and actors, and no flourishing pediatric radiologist can disavow moral responsibility.

\section{Gratitude}

Recognizing and responding to threats to human flourishing has a flip side - when the opportunity presents itself, indulging the habit of feeling and expressing gratitude.

We have so much to be grateful for - a vast and growing knowledge base and a more impressive diagnostic and therapeutic armamentarium than medicine has enjoyed at any point in human history. Too soon we grow inured to the incredible resources at our fingertips, only indulging our frustration when some aspect of the system fails.

There are parts of the world where things don't come so easily, where a child who needs a diagnostic or therapeutic imaging procedure might not have access to it, because the technology is unavailable, those on hand are not educated to use it properly, the means to pay for such an examination are lacking, or because the resources are inaccessible from geographic or political circumstances.

What a blessing it is to simply click a box and know that the procedure will be performed within minutes!

So much that we take for granted is not the fruit of our own labors. How many of the concepts in textbooks of pediatric radiology are any single pediatric radiologist responsible for? What role did each of us play in discovering or inventing Xrays, ultrasound, CT or MRI, and what contribution did we make to defining their appropriate clinical uses?

We see so far because we are perched on the shoulders of giants. How often do we pause to acknowledge the profound gratitude we owe them?

\section{Faithfulness}

Finally, flourishing as a pediatric radiologist requires the habit of faithfulness. Who taught us this art, and who taught it to our teachers? What aspirations animated the great figures and communities in the history of our field, and to what degree are we striving each day to live up to the ideals that animated them?

To be faithful means recognizing that the future depends somewhat on how we operate in the present, and to live up to that responsibility in everything we do.

We are stewards of something that transcends us - an art that existed and flourished long before we came on the scene and will persist long after we are gone. This is not a legacy we own, and the light of this torch we bear is not one that we first ignited.

We are but links in a long chain, and faithfulness to that chain means recognizing that it is more important than we are. It is not our tool. It would be truer to say that, for the time being, we are its instruments.

Yet we are not mere custodians. Merely maintaining the status quo is an admission of failure.

Faithfulness means moving forward into the unknown, making the most of our incomplete knowledge, our commitment to collegiality, our capacity for courage, and our gratitude for all that we have been given.

It means addressing the challenges before us in a way that not merely solves the problem at hand but creates conditions for our patients, colleagues and neighbors to thrive in the future.

\section{Conclusion}

It is no admission of failure to say that we have done the best we could. Yet this is no excuse to offer less than our best. We all make mistakes, and sometimes people suffer. 
Yet if we learn as much as we can from each error, redouble our efforts to choose appropriately the next time, and celebrate such contributions as we can make, we will have acted admirably.

When the time comes to pass the torch to our successors, we will be able to say to one another, "Well done, good and faithful servant."

\section{Compliance with ethical standards}

Conflicts of interest None

Publisher's note Springer Nature remains neutral with regard to jurisdictional claims in published maps and institutional affiliations. 